ISSN 0103-5150

Fisioter. Mov., Curitiba, v. 28, n. 2, p. 213-221, Apr./June 2015

Licenciado sob uma Licença Creative Commons DOI: http://dx.doi.org.10.1590/0103-5150.028.002.A001

\title{
Use of custom insoles for redistributing plantar pressure, decreasing musculoskeletal pain and reducing postural changes in obese adults
}

\author{
Uso da palmilha para redistribuir a pressão plantar, \\ diminuir a dor musculoesquelética e reduzir as \\ alterações posturais em adultos obesos
}

\author{
Elisa Isis Ferreira ${ }^{[a]}$, Carlos Alberto Vargas Ávila ${ }^{[b]}$, Marco Fabio Mastroeni ${ }^{[c] *}$ \\ [a] Associação Catarinense de Ensino (ACE), Departamento de Fisioterapia, Joinville, SC, Brazil \\ [b] Fundação Universidade Regional de Blumenau (FURB), Departamento de Educação Física, Blumenau, SC, Brazil \\ [c] Universidade da Região de Joinville (Univille), Joinville, SC, Brazil
}

\section{Abstract}

Introduction: Insoles are used for different purposes and they can be an additional factor aiding weight loss in obese people due to their contribution in reducing musculoskeletal pain. Objective: The aim of the present study was to assess the effect of custom insoles for redistributing plantar pressure, decreasing musculoskeletal pain and reducing postural changes in obese adults. Materials and methods: Data was obtained from morbidly obese people, who had a Body Mass Index (BMI) $\geq 35$ and $<45 \mathrm{~kg} / \mathrm{m}^{2}$, at three moments: before the insole was provided, immediately after insole use began and after two months of use. Anthropometric, postural, musculoskeletal pain and computerized baropodometry data were collected. Results: When comparing the stages before the use of the insole and after two months of use, significant $(p<0.05)$ decreases were observed in the number of people with right lateral postural misalignment, in the

* EIF: MSc, e-mail: elisa@podoclinicpalmilhas.com.br CAVA: MSc, e-mail: cavila@furb.br

MFM: PhD, e-mail: marco.mastroeni@univille.br 
intensity of the musculoskeletal pain of the body segments evaluated (except for the right knee), and in the mean of the peak plantar pressure values. In terms of total plantar contact area, the mean increased significantly $(\mathrm{p}<0.05)$ in both right and left feet after the intervention. Conclusion: This study demonstrated that the daily use of proprioceptive insoles contributed to reducing peak plantar pressure, musculoskeletal pain and lateral postural deviations. The use of proprioceptive insoles may be an important strategy to encourage obese people to exercise and, consequently, reduce weight.

Keywords: Plantar pressure. Excess weight. Rehabilitation. Musculoskeletal pain. Posture.

\section{Resumo}

Introdução: Palmilhas têm sido utilizadas por diferentes razões, e podem auxiliar na perda de peso em pessoas obesas por contribuírem na redução da dor musculoesquelética. Objetivos: 0 objetivo do presente estudo foi avaliar o efeito da palmilha na redistribuição da pressão plantar, na diminuição da dor musculoesquelética e na redução das alterações posturais em adultos obesos. Materiais e métodos: Os dados foram obtidos de pacientes com obesidade mórbida e Índice de Massa Corporal (IMC) $\geq 35$ e $<45 \mathrm{~kg} / \mathrm{m}^{2}$, em três diferentes momentos: antes do fornecimento da palmilha, imediatamente após o uso da palmilha e após dois meses de uso da palmilha. Foram coletados dados relacionados à antropometria, postura, dor musculoesquelética e baropodometria computadorizada. Resultados: Quando comparadas as etapas antes do uso das palmilhas e após dois meses de uso, houve redução significativa $(p<0,05)$ no número de indivíduos com desvio lateral direito, na intensidade da dor musculoesquelética dos segmentos corporais avaliados (exceto para o joelho direito) e nos valores médios dos picos de pressão plantar. No que tange à área total de contato plantar, sua média aumentou de forma significativa $(p<0,05)$ em ambos os pés, direito e esquerdo, após a intervenção. Conclusão: Este estudo demonstrou que o uso diário de palmilhas proprioceptivas contribuiu na redução dos picos de pressão plantar, da dor musculoesquelética e dos desvios posturais laterais. $O$ uso de palmilhas proprioceptivas pode ser uma importante estratégia para estimular indivíduos obesos a praticarem exercícios e, consequentemente, reduzirem seu peso.

Palavras-chave: Pressão plantar. Excesso de peso. Reabilitação. Dor musculoesquelética. Postura.

\section{Introduction}

Obesity is a chronic non-transmissible disease that causes several morphophysiological changes in the subject, including the adaptation of the musculoskeletal system, as a result of the excess body weight (1). Excess weight negatively affects the joints of the lower limbs and can cause their misalignment (2), metatarsalgia (3), osteoarthritis $(4,5)$, limitations in muscle strength, decreased mobility, and altered positioning of the feet, which affects the posture (6). Obesity also increases the ground contact area of the feet, altering the plantar pressure distribution and inducing pressure peaks in certain parts of the foot $(7,8)$. The peak plantar pressure is the highest pressure registered on each part of the foot, and its evaluation provides a strong clinical tool for understanding the structural and functional consequences of obesity (9). Custom insoles provide an interface between the shoe and the foot and can be used to reduce the peak plantar pressure, increase afferent input from plantar mechanoreceptors, improve plantar pressure distribution and postural control (10), decrease pain (11), assist a misaligned foot to adapt to the environment and reduce the frequency of injury (12). Custom posture control insoles have been used for decades, and can be an additional factor aiding weight loss in obese people, because they significantly reduce musculoskeletal pain $(13,14)$. With less pain and postural repositioning, especially in the lower limb joints, obese people will have better mobility and could develop more activities, even sports. This greater mobility may assist in reducing body weight in the medium term, possibly avoiding the need for bariatric surgery. The aim of the present study was to verify the effects of custom proprioceptive insoles on plantar pressure redistribution, musculoskeletal pain, and postural changes in obese adults. 


\section{Materials and methods}

The convenience sample was constituted by individuals registered in an association for morbidly obese people in Joinville, Santa Catarina state, Brazil, who had a Body Mass Index (BMI) $\geq 35$ and $<45 \mathrm{~kg} / \mathrm{m}^{2}$ and were receiving clinical monitoring prior to bariatric surgery in the period between January 2009 and January 2011. Thirty-seven subjects were selected and composed the study sample (Figure 1).

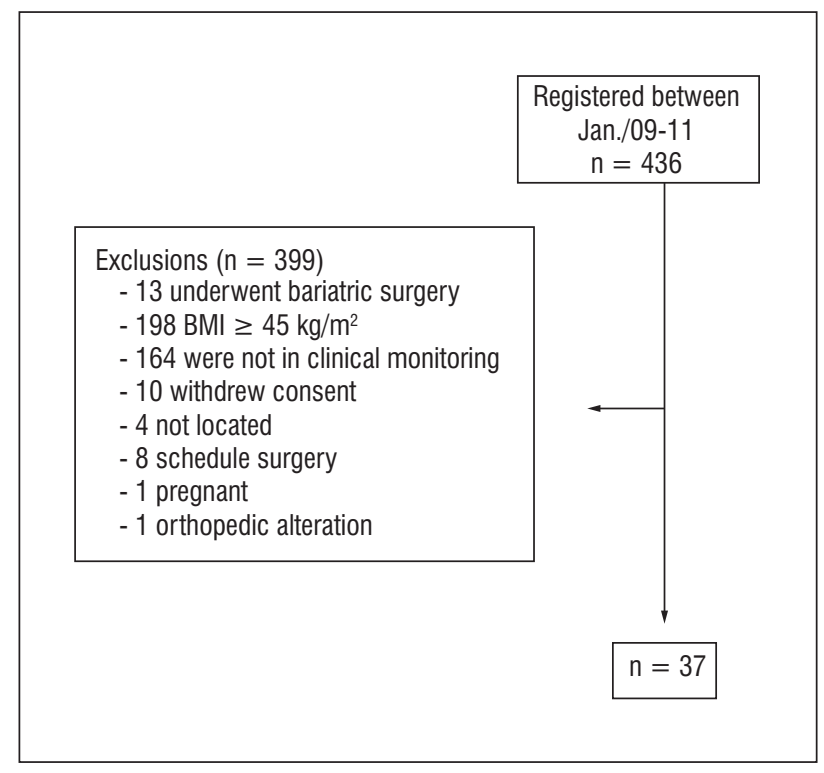

Figure 1 - Flow chart of subjects

With the information obtained from the association for morbidly obese people, the volunteers were contacted and invited to participate in the study. Before commencing the study, all procedures and methods were approved by the Ethics Committee for Human Research, Hans Dieter Schmidt Regional Hospital, Joinville (SC), case No. 026/2010. All study subjects freely signed the informed consent form.

Data collection was organized in two stages; the first occurred in February 2011, when the subjects were questioned regarding their socio-economic status and demographic profile. At this stage, the volunteers were evaluated in relation to anthropometric measurements, postural analysis (anterior, posterior, and lateral views), musculoskeletal pain, and baropodometry.

After the evaluations, the custom insoles were made according to the characteristics of each subject. Immediately afterward, the volunteers began wearing the insoles and were evaluated again through postural analysis and baropodometry. In addition to the insoles, each volunteer also received a form to record the number of hours of insole use per day over the following two months. The second stage occurred in April 2011, after two months of wearing the insoles, when the subjects were evaluated again regarding posture, pain, and baropodometric variables. In the second stage, data were collected individually, over approximately 60 minutes, in a physiotherapy clinic. During the study period, the activities the volunteers performed prior to the study remained unchanged: They did not practice physical activity, diet or use drugs to reduce weight.

The anthropometric evaluation was performed by taking weight and height measurements. The volunteers' weight was assessed on a digital scale W-835 (Wiso, China) with a capacity of $180 \mathrm{~kg}$ and divisions of 100 g. Height was measured with a portable stadiometer Seca" (TBW, São Paulo, BR), with a measuring range of $0-220 \mathrm{~cm}$ and graduations of $1 \mathrm{~mm}$. After obtaining the weight and height, the BMI was calculated by dividing the weight in kilograms by the square of the height in meters. Classification of BMI values was based on the criteria established by the World Health Organization (15).

The evaluation of anterior, posterior and lateral postural variations was carried out with the aid of a Simetrograph, WCS ${ }^{\text {min }}$ (Cardiomed, Curitiba, BR), and pain was measured using a Visual Analog Pain Scale (VAS).

The baropodometric analysis was conducted using pressure sensor insoles connected by eight-meter wires to an F-Scan ${ }^{\text {'m }}$ baropodometer (Tekscan, Boston, USA). The analysis was performed simultaneously for both feet with the patient in a standing position, thus obtaining both static and dynamic data (standing and walking). The analysis of the data was carried out using Cavanagh's criteria (16), which categorize the plantar region in three main parts: forefoot, midfoot and hindfoot.

Comfort model "' baropodometer (Podaly, Brusque, $\mathrm{BR}$ ) insoles were manufactured according to the characteristics of each patient from the data collected in the baropodemetric analysis. Obese people have greater difficulty wearing closed shoes, and to ensure compliance, subjects were instructed to wear them for at least six hours a day until the second stage of the study, when new evaluations were made.

Data analysis was performed using the Statistical Package for the Social Sciences (SPSS), version 17.0 
software. Continuous variables were presented as means and standard deviations ( $S D$ ). For data analysis, to compare two means with non-normal distributions, Wilcoxon's non-parametric test was used. To examine differences in postural evaluation between phases the McNemar test was used. Data normality was verified using the Kolmogorov-Smirnov test. All tests were considered significant when $\mathrm{p}<0.05$.

\section{Results}

Of the 37 individuals selected for the first stage of the study, five did not participate in the second stage. Three of them underwent bariatric surgery during the data collection, and two of them refused to continue in the research, leaving a total of 32 individuals for the second stage.

The mean age of the subjects was 39.9 years $(S D=$ 11.8 years); the minimum and maximum ages were 21 and 59 years, respectively. The socio-demographic characteristics are described in Table 1 . The majority of the individuals (87.5\%) were female, aged 40 or older, elementary school graduates (56.3\%), married $(81.3 \%)$ and with a monthly household income equal to or greater than four minimum salaries (Table 1). The mean BMI and weight before insole use were significantly higher $(\mathrm{p}<0.05)$ than after two months of use (BMI: $41.6 \pm 2.7 \mathrm{~kg} / \mathrm{m}^{2}$ vs. $41.2 \pm 2.7 \mathrm{~kg} / \mathrm{m}^{2}$; Weight: $108.9 \pm 12.0 \mathrm{~kg}$ vs. $107.8 \pm 11.8 \mathrm{~kg}$ ).
For the postural data evaluation, the McNemar test showed a significant $(p=0.039)$ decrease in the number of people with right lateral misalignment two months after the intervention began (14 to 7). There was also a reduction in the number of subjects with left lateral misalignment (11 to 9), however, this was not statistically significant $(p=0.687)$. There was no reduction in the number of people with anterior and posterior postural deviations in the same period.

The Wilcoxon test revealed a significant reduction in the intensity of musculoskeletal pain in the body segments evaluated before and after the use of the proprioceptive insoles for two months, with the exception of the right knee (Table 2).

The data of the peaks of plantar pressure and the total area of plantar contact of the obese subjects, according to the stage of the study, are shown in Table 3. There were no significant differences between the mean peak plantar pressure and the total area of plantar contact in the three regions of both feet when comparing pre-intervention (before insoles) values to those after two months of insole use. The same variables were compared for the point immediately after insole use began and two months later; there was a significant $(p<0.05)$ reduction of the mean of peak plantar pressure values only in the right foot. In terms of total plantar contact area, the mean increased significantly $(p<0.05)$ in both feet after the intervention (Table 3).

Table 1 - Socio-demographic characteristics of the obese adults, according to absolute (n) and relative (\%) frequencies. Joinville, SC, Brazil, 2010

(To be continued)

\begin{tabular}{lcc}
\hline Characteristics & $\mathbf{n}$ & \% \\
\hline Sex & & 12.5 \\
Male & 4 & 87.5 \\
Female & 28 & 31.3 \\
\hline Age (years) & 10 & 21.9 \\
$<30$ & 7 & 46.9 \\
30 to 39.9 & 15 & 43.8 \\
$\geq 40$ & & 56.3
\end{tabular}


Table 1 - Socio-demographic characteristics of the obese adults, according to absolute (n) and relative (\%) frequencies. Joinville, SC, Brazil, 2010

(Conclusion)

\begin{tabular}{lrc}
\hline Characteristics & $\mathbf{n}$ & $\%$ \\
\hline Marital status & & \\
Married/unmarried unions & 26 & 81.3 \\
Others & 6 & 18.8 \\
\hline Household income $(\mathrm{MS}=\$ 328.00)$ & & 3.1 \\
$<2$ & 1 & 18.8 \\
2 to 3 & 6 & 78.1 \\
$\geq 4$ & 25 & \\
\hline
\end{tabular}

Note: MS = minimum salary, in US dollars.

Table 2 - Absolute frequency (n), mean and standard deviation (SD) for pain before and after two months of insole use by obese adults, according to the anatomic region. Joinville, SC, Brazil, 2010

\begin{tabular}{|c|c|c|c|c|c|c|}
\hline \multirow{2}{*}{ Anatomic region } & \multirow{2}{*}{$\mathrm{n}$} & \multicolumn{2}{|c|}{ Before insole use } & \multicolumn{2}{|c|}{ After two months of insoles use } & \multirow{2}{*}{$p^{*}$} \\
\hline & & Mean & $S D$ & Mean & $S D$ & \\
\hline Lumbar Spine & 19 & 7.9 & 1.6 & 5.4 & 2.7 & $<0.001$ \\
\hline Right knee & 8 & 7.2 & 2.2 & 5.6 & 1.9 & 0.084 \\
\hline Left knee & 8 & 8.3 & 1.0 & 4.8 & 2.6 & 0.027 \\
\hline Right leg & 7 & 6.5 & 2.1 & 2.4 & 1.9 & 0.028 \\
\hline Left leg & 8 & 7.3 & 1.5 & 2.6 & 2.3 & 0.018 \\
\hline Right foot & 17 & 7.7 & 2.0 & 4.6 & 3.4 & $<0.001$ \\
\hline Left foot & 16 & 7.8 & 1.5 & 4.4 & 3.4 & $<0.001$ \\
\hline
\end{tabular}

Note: *Wilcoxon Test.

Table 3 - Means and standard deviations (SD) of the peaks of plantar pressure and the total area of plantar contact of the obese subjects, according to the stage of the study. Joinville, SC, Brazil, 2010

(To be continued)

\begin{tabular}{|c|c|c|c|c|c|c|}
\hline \multirow[t]{2}{*}{ Variables } & \multicolumn{2}{|c|}{ Before insoles } & \multicolumn{2}{|c|}{$\begin{array}{l}\text { Immediately after insole } \\
\text { use began }\end{array}$} & \multicolumn{2}{|c|}{$\begin{array}{l}\text { After two months of } \\
\text { insoles use }\end{array}$} \\
\hline & Mean & $S D$ & Mean & $S D$ & Mean & $S D$ \\
\hline \multicolumn{7}{|c|}{ Peak plantar pressure } \\
\hline \multicolumn{7}{|l|}{ Right foot } \\
\hline Total & $6.4^{*}$ & 3.7 & 9.0 & 5.2 & 5.6 & 1.9 \\
\hline Forefoot & $7.4^{*}$ & 3.4 & 11.1 & 6.5 & 7.2 & 2.7 \\
\hline Midfoot & $6.8^{*}$ & 7.7 & 9.7 & 7.8 & 5.3 & 1.9 \\
\hline Hindfoot & $4.9^{*}$ & 2.8 & 6.3 & 4.2 & 4.5 & 2.0 \\
\hline
\end{tabular}


Table 3 - Means and standard deviations (SD) of the peaks of plantar pressure and the total area of plantar contact of the obese subjects, according to the stage of the study. Joinville, SC, Brazil, 2010

(Conclusion)

\begin{tabular}{|c|c|c|c|c|c|c|}
\hline \multirow[t]{2}{*}{ Variables } & \multicolumn{2}{|c|}{ Before insoles } & \multicolumn{2}{|c|}{$\begin{array}{c}\text { Immediately after insole } \\
\text { use began }\end{array}$} & \multicolumn{2}{|c|}{$\begin{array}{l}\text { After two months of } \\
\text { insoles use }\end{array}$} \\
\hline & Mean & $S D$ & Mean & $S D$ & Mean & $S D$ \\
\hline \multicolumn{7}{|l|}{ Left foot } \\
\hline Total & 6.0 & 3.0 & 6.5 & 2.9 & 5.7 & 2.2 \\
\hline Forefoot & 7.8 & 3.9 & 9.1 & 5.6 & 7.8 & 3.7 \\
\hline Midfoot & 5.7 & 4.6 & 5.3 & 1.9 & 4.9 & 2.3 \\
\hline Hindfoot & 4.5 & 2.1 & 5.2 & 3.1 & 4.4 & 1.9 \\
\hline \multicolumn{7}{|c|}{ Total area of the foot } \\
\hline Right & $117.4^{*}$ & 21.5 & 107.3 & 23.7 & 120.2 & 19.9 \\
\hline Left & $123.9^{*}$ & 26.8 & 125.6 & 21.4 & 131.7 & 17.3 \\
\hline
\end{tabular}

Note: ${ }^{*}<<0.05$, significant difference with "after two months of insoles use". Wilcoxon test.

\section{Discussion}

Several studies in the scientific literature involving the evaluation of plantar pressure in obese individuals have shown that their mean peak plantar pressure is greater than that of eutrophic individuals $(7,9,17,18)$. However, there have been few studies of interventions with insoles in obese people or that show the relationship between insole use and postural changes. In this respect, the findings of the present study demonstrate that the use of proprioceptive insoles as a coadjuvant treatment to reduce musculoskeletal pain has a beneficial effect. Insole use is also associated with several baropodometric and postural changes that will be further discussed.

Obese individuals are more likely to present orthopedic disorders, primarily postural deviations, as a result of several factors, such as joint overloading, a decrease in postural stability, and an increase in energy expenditure while performing normal activities (19). The joint misalignments caused by obesity affect the lower limbs and cause pain at an early age (2). Postural control can also be influenced by strength and range of motion limitations, pain or the positioning of the feet (6). The improvement of postural control through the use of insoles alters the activity of the plantar nerve receptors and stimulates the sensorimotor system (20). Postural change was also verified in this study; reduction in the percentage of individuals with right lateral postural deviations after two months of using proprioceptive insoles was observed. In this case, the reduction of unilateral musculoskeletal pain led to a reduction in the burden on the asymptomatic side of the body. In addition, the postural bars placed inside the insoles affected the postural adjustment. However, there was no reduction in the anterior displacement of the body, which can be explained by the fact that the individuals did not lose weight over the two months of the intervention; their large abdomens and breasts maintained the forward displacement of the center of gravity. Other studies have also found similar results with respect to posture $(2,6)$, however, there are no studies on the use of insoles for postural correction in obese people.

When musculoskeletal pain was investigated, the use of insoles significantly reduced the pain in the body parts evaluated, with the exception of the right knee. It is believed that the reduction of pain occurred because of the repositioning of the joints of the lower limbs, which are exposed to the burden of the body weight. Influenced by the insoles, this repositioning relieved the muscular, ligament and joint tension and therefore eased the pain. This result is important because several studies have reported the presence of pain in obese individuals $(2,14,21-23)$, especially in the lower limbs and in the lumbar spine $(13,24)$. Some authors have also reported a greater frequency of tendinopathies in these individuals (25).

Lower back pain in obese people is often caused by excess weight and the forward displacement of 
the center of gravity, which forces the lumbar spine to help maintain postural balance and therefore causes pain. In this study, after eight weeks of using custom insoles as the only intervention, there was a $31.8 \%$ reduction in lower back pain in the individuals investigated, revealing the therapeutic potential of this type of treatment. Another intervention study (13) found even higher values with obese individuals. According to these authors, there was a $40.6 \%$ reduction in lower back pain after 6-12 weeks of intense physical therapy without the use of insoles. In this study, subjects with an average BMI of less than $30 \mathrm{~kg} / \mathrm{m}^{2}$, i.e., individuals with a lower weight, felt less pain in the lumbar region.

In addition to lumbar pain, the volunteers in the present study also reported pain in the feet. The data obtained showed reductions of $39.7 \%$ and $43.6 \%$ in the pain in the right and left feet, respectively, after two months of intervention. A positive effect due to the use of insoles for pain reduction was also found by some authors, with a reduction of $46.0 \%$ in foot pain on the first day of use of the insoles and a further $73.2 \%$ reduction after one month (22). We believe that the lower mean BMI of their subjects $\left(22.5 \mathrm{~kg} / \mathrm{m}^{2}\right)$ accounts for the difference in pain reduction compared to that of the present study. In other words, conservative treatment of musculoskeletal pain is more effective in non-obese individuals.

Several studies conducted with people with osteoarthritic pain have revealed that obesity can be one of its causes $(4,5,11,26-28)$. One study reported a $59.3 \%$ reduction in knee pain after one month of insole use in eutrophic individuals (11). Other authors have revealed that, in addition to reducing pain, insoles have improved the functionality of the knees $(29,30)$. The use of insoles can also reduce biomechanical changes at the knee during walking, reducing the risk and progression of osteoarthritis $(4,31-33)$. The data obtained in the present study suggest that the $22.3 \%$ decrease in pain in the right knee and $41.7 \%$ decrease in the left knee are related to the levels of lateral postural deviation, as there was a reduction of $50.0 \%$ and $18.2 \%$ in the number of individuals diagnosed with lateral deviation on the right and left side, respectively, after the intervention. That is, individuals who do not display lateral deviations have less pain due to the reduction of excessive weight.

Another important aspect of this study concerns the reduction of peak plantar pressure before and after the intervention. After two months of using the custom insoles, there was a reduction in the mean peak plantar pressure values in the three regions of both feet. In contrast, there was also an increase in the mean values of the total area of plantar contact for both feet. Although these changes were not significant from a statistical perspective, this result was expected because whenever the contact area increases with no weight loss, a reduction of plantar pressure consequently occurs. The pressure values immediately after insole use began were compared with the data obtained two months later. The mean peak plantar pressure was higher than the values obtained in the pre-intervention and two month stages; the reduction of these values between the two stages was also higher. That is, the mean peak plantar pressure values obtained after two months of intervention were lower than the pre-intervention values $36.9 \%$ for the right foot and $11.7 \%$ for the left foot). This reduction of plantar pressure with the use of insoles may be caused by increased foot contact area, changing the positioning of the feet on the insoles, aligning the joints and reducing the stress on tendons and ligaments. Similar results have also been reported by other authors, who demonstrated a reduction in pain with the redistribution of plantar pressure in the three regions of the feet $(3,34)$. The use of custom insoles can significantly reduce the risk of osteoarthritis progression, this being a simple and cheap treatment (27).

Our results were similar to those of other studies with obese individuals, revealing that the highest peak plantar pressure occurred in the forefoot region, due to forward displacement of the center of gravity $(1,35)$. Even though these peaks of plantar pressure were higher in the forefoot region, they were reduced in both feet after two months of intervention.

The limitations of this study are partially a result of the size of the sample, as studies involving few people make it difficult to pinpoint differences among the subgroups and increase the sampling error.

\section{Conclusion}

The results of this study show that the daily use of proprioceptive insoles contributed to the reduction of peak plantar pressure, musculoskeletal pain and lateral deviations. The adoption of custom insoles by patients who have been selected to undergo bariatric surgery can stimulate them to increase their physical activity, thus reducing their weight and avoiding the 
surgical procedure. However, we suggest that further studies should be conducted with larger samples and over longer periods of investigation.

\section{Acknowledgments}

We thank the Department of Physical Education of the University of Blumenau, Santa Catarina, Brazil, for the loan of the F-Scan equipment; and the Joinville Association of Morbid Obesity for allowing the use of the data. This study was supported by research grants from the University of Joinville Region.

\section{References}

1. Bankoff ADP, Zamai CA, Schimdt A, Ciol P, Barros DD. Estudo das alterações morfológicas do sistema locomotor: postura corporal × obesidade. Rev Edu Física/ UEM. 2008;14(2):41-8.

2. Pinto ALS, Holanda PMB, Radu AS, Villares SM, Lima FR. Musculoskeletal findings in obese children. J Paediatr Child Health. 2006;42(6):341-4.

3. Chang B-C, Wang J-Y, Huang B-S, Lin H-Y, Lee WC. Dynamic impression insole in rheumatoid foot with metatarsal pain. Clin Biomech (Bristol, Avon). 2012; 27(2):196-201.

4. Russell EM, Hamill J. Lateral wedges decrease biomechanical risk factors for knee osteoarthritis in obese women. J Biomech. 2011;44(12):2286-91.

5. Lee R, Kean W. Obesity and knee osteoarthritis. Inflammopharmacology. 2012;20(2):53-8. doi: 10.1007/ s10787-011-0118-0.

6. Horak FB. Postural orientation and equilibrium: what do we need to know about neural control of balance to prevent falls? Age Ageing. 2006;35(Suppl 2):ii7-11. doi: 10.1093/ageing/afl077.

7. Lee YS. The role of genes in the current obesity epidemic. Ann Acad Med Singapore. 2009;38(1):45-3.

8. Dowling AM, Steele JR, Baur LA. Does obesity influence foot structure and plantar pressure patterns in prepubescent children? Int J Obes Relat Metab Disord. 2001;25(6):845-52. doi: 10.1038/sj.ijo.0801598.
9. Filippin N, Barbosa V, Sacco I, da Costa PL. Effects of obesity on plantar pressure distribution in children. Rev Bras Fisioter. 2007;11(6):495-501.

10. Qiu F, Cole MH, Davids KW, Hennig EM, Silburn PA, Netscher H, et al. Enhanced somatosensory information decreases postural sway in older people. Gait Posture. 2012;35(4):630-5. doi: 10.1016/j. gaitpost.2011.12.013.

11. Turpin KM, De Vincenzo A, Apps AM, Cooney T, MacKenzie MD, Chang R, et al. Biomechanical and clinical outcomes with shock-absorbing insoles in patients with knee osteoarthritis: immediate effects and changes after 1 month of wear. Arch Phys Med Rehabil. 2012;93(3):503-8. doi: 10.1016/j.apmr.2011.09.019.

12. Bateni H. Changes of postural steadiness following use of prefabricated orthotic insoles. J Appl Biomech. 2013;29(2):174-9.

13. Mangwani J, Giles C, Mullins M, Salih T, Natali C. Obesity and recovery from low back pain: a prospective study to investigate the effect of body mass index on recovery from low back pain. Ann R Coll Surg Engl. 2010;92(1):23-6. doi: 10.1308/003588410x12518 836438967.

14. Stone AA, Broderick JE. Obesity and pain are associated in the United States. Obesity (Silver Spring). 2012;20(7):1491-5. doi: 10.1038/oby.2011.397.

15. World Health Organization. Obesity: preventing and managing the global epidemic. Report of a WHO consultation. World Health Organ Tech Rep Ser. 2000;894:i-xii, 1-253.

16. Cavanagh PR, Rodgers MM. The arch index: a useful measure from footprints. J Biomech. 1987;20(5): 547-51.

17. Birtane $\mathrm{M}$, Tuna $\mathrm{H}$. The evaluation of plantar pressure distribution in obese and non-obese adults. Clin Biomech (Bristol, Avon). 2004;19(10):1055-9. doi: 10.1016/j.clinbiomech.2004.07.008.

18. Hills AP, Hennig EM, McDonald M, Bar-Or O. Plantar pressure differences between obese and non-obese adults: a biomechanical analysis. Int J Obes Relat Metab Disord. 2001;25(11):1674-9. doi: 10.1038/ sj.ijo.0801785.

19. Brandalize M, Leite N. Orthopedic alterations in obese children and adolescents. Fisioter Mov. 2010; 23(2):283-8. 
20. McKeon PO, Stein AJ, Ingersoll CD, Hertel J. Altered plantar-receptor stimulation impairs postural control in those with chronic ankle instability. J Sport Rehabil. 2012;21(1):1-6.

21. Bihari V, Kesavachandran C, Pangtey BS, Srivastava AK, Mathur N. Musculoskeletal pain and its associated risk factors in residents of National Capital Region. Indian J Occup Environ Med. 2011;15(2):59-63. doi: 10.4103/0019-5278.90375.

22. Chan G, Chen CT. Musculoskeletal effects of obesity. Curr Opin Pediatr. 2009;21(1):65-70. doi: 10.1097/ MOP.0b013e328320a914.

23. Hills AP, Hennig EM, Byrne NM, Steele JR. The biomechanics of adiposity: structural and functional limitations of obesity and implications for movement. Obes Rev. 2002;3(1):35-43.

24. Cimolin V, Vismara L, Galli M, Zaina F, Negrini S, Capodaglio P. Effects of obesity and chronic low back pain on gait. J Neuroeng Rehabil. 2011;8:55. doi: 10.1186/ 1743-0003-8-55.

25. Battery L, Maffulli N. Inflammation in overuse tendon injuries. Sports Med Arthrosc. 2011;19(3):213-7. doi: 10.1097/JSA.0b013e31820e6a92.

26. Chacur EP, Silva L, Luz GCP, Silva PLd, Baraúna MA, Cheik NC. Obesidade e sua correlação com a osteoartrite de joelho em mulheres. Fisioter Mov. 2008; 21(2):93-8.

27. Hinman RS, Bennell KL. Advances in insoles and shoes for knee osteoarthritis. Curr Opin Rheumatol. 2009;21(2):164-70. doi: 10.1097/ BOR.0b013e32832496c2.

28. Sinusas K. Osteoarthritis: diagnosis and treatment. Am Fam Physician. 2012;85(1):49-56.

29. Erhart JC, Mundermann A, Elspas B, Giori NJ, Andriacchi TP. Changes in knee adduction moment, pain, and functionality with a variable-stiffness walking shoe after 6 months. J Orthop Res. 2010;28(7):873-9. doi: 10.1002/jor.21077.

30. Kutzner I, Damm P, Heinlein B, Dymke J, Graichen F, Bergmann G. The effect of laterally wedged shoes on the loading of the medial knee compartmentin vivo measurements with instrumented knee implants. J Orthop Res. 2011;29(12):1910-5. doi: $10.1002 /$ jor.21477.
31. Fantini Pagani CH, Hinrichs M, Bruggemann GP. Kinetic and kinematic changes with the use of valgus knee brace and lateral wedge insoles in patients with medial knee osteoarthritis. J Orthop Res. 2012;30(7):1125-32. doi: 10.1002/jor.22032.

32. Kuroyanagi Y, Nagura T, Matsumoto H, Otani T, Suda Y, Nakamura T, et al. The lateral wedged insole with subtalar strapping significantly reduces dynamic knee load in the medial compartment gait analysis on patients with medial knee osteoarthritis. Osteoarthritis Cartilage. 2007;15(8):932-6. doi: 10.1016/j. joca.2007.02.004.

33. Toda Y, Tsukimura N. Influence of concomitant heeled footwear when wearing a lateral wedged insole for medial compartment osteoarthritis of the knee. Osteoarthritis Cartilage. 2008;16(2):244-53. doi: 10.1016/j. joca.2007.06.010.

34. Stolwijk NM, Louwerens JW, Nienhuis B, Duysens J, Keijsers NL. Plantar pressure with and without custom insoles in patients with common foot complaints. Foot Ankle Int. 2011;32(1):57-65. doi: 10.3113/fai. 2011.0057.

35. Kanatli U, Yetkin H, Simsek A, Ozturk AM, Esen E, Besli K. [Pressure distribution patterns under the metatarsal heads in healthy individuals]. Acta Orthop Traumatol Turc. 2008;42(1):26-30.

Received: 08/08/2013 Recebido: 08/08/2013

Approved: 03/03/2015 Aprovado: 03/03/2015 